\title{
Analysis of PDE6D and PDE6G genes for generalised progressive retinal atrophy (gPRA) mutations in dogs
}

\author{
Gabriele Dekomien*, Joerg T. Epplen \\ Human Genetics, Ruhr-University, 44780 Bochum, Germany
}

(Received 1st August 2002; accepted 26 November 2002)

\begin{abstract}
The $\delta$ and $\gamma$ subunits of the cGMP-phosphodiesterase (PDE6D, PDE6G) genes were screened in order to identify mutations causing generalised progressive retinal atrophy (gPRA) in dogs. In the PDE6D gene, single nucleotide polymorphisms (SNP) were observed in exon 4, in introns 2 and 3 and in the $3^{\prime}$ untranslated region (UTR) of different dog breeds. In the coding region of the $P D E 6 G$ gene, exclusively healthy Labrador Retrievers showed an $\mathrm{A} \rightarrow \mathrm{G}$ transition in exon 4 without amino acid exchange. SNP were also observed in introns 1 and 2 in different dog breeds. The different SNP were used as intragenic markers to investigate the involvement of both genes in gPRA. The informative substitutions allowed us to exclude mutations in the $P D E 6 D$ and $P D E 6 G$ genes as causing retinal degeneration in 15 of the 22 dog breeds with presumed autosomal recessively transmitted (ar) gPRA.
\end{abstract}

cGMP-phosphodiesterase / canine / generalised progressive retinal atrophy / SNP / retinitis pigmentosa / SSCP

\section{INTRODUCTION}

Rod cGMP-phosphodiesterase (PDE) is the G-protein-activated effector enzyme that regulates the level of cGMP in vertebrate photoreceptor cells [3, 13]. Rod cGMP PDE is generally viewed as a protein composed of catalytic $\alpha$ and $\beta$ subunits, two identical inhibitory $\gamma$ subunits [30] and a $\delta$ subunit. Respective DNA sequences were recently identified in men, mice, cows and dogs [15,20,21]. The exact function of the $\delta$ subunit is still not known, since in vitro it does not affect the catalytic activity of PDE. Loss of $\gamma$ subunits entails reduced hydrolytic activity and leads to an increased PDE activity [32].

Defects in genes encoding PDE subunits have been associated with retinal disease in humans and several animal models [5,6,16,20,22,26,31,32]. For autosomal recessively transmitted (ar), generalised progressive retinal atrophy

\footnotetext{
* Correspondence and reprints

E-mail: gabriele.dekomien@ruhr-uni-bochum.de
} 
(gPRA), the most common hereditary form in dogs, mutations have been identified in the $\beta$ subunit of the PDE (PDE6B) gene in Irish Setters and Sloughis [12, 31 ] and in the $\alpha$ subunit (PDE6A) gene in Cardigan Welsh Corgis [25].

Retinitis pigmentosa (RP) in man is the homologous disease to gPRA in dogs. Ar transmitted forms of RP have been mapped to the $\delta$ subunit (PDE6D; 2q35-36; RP26) and to the $\gamma$ subunit genes in man (PDE6G; 17q25 RP17; RetNet: http://www.sph.uth.tmc.edu/Retnet/). On the basis of reciprocal chromosome painting the canine $P D E 6 D$ gene is, therefore, predicted to map to CFA 25 [7] and the $P D E 6 G$ gene to CFA 9 [36], the homologous chromosomal regions in dogs. These genes were recently excluded for rod-cone dysplasia 2 $(r c d 2)$ in collies [34], but mutations in these genes could cause gPRA in other breeds. Therefore, these genes were investigated as candidate genes for gPRA in 22 different breeds including gPRA affected dogs.

\section{MATERIALS AND METHODS}

\subsection{Animals}

The blood of 808 dogs from 22 different breeds including 114 gPRA-affected animals (see Tab. I) was received from the owners in cooperation with breeding organisations. The blood of most dogs was obtained from different regions of Germany. In addition, several Saarloos Wolfdogs (Sa), Schapendoes (SD), Sloughi (Sl) and Tibetan Terriers (TT) originated from the Netherlands (Sa, $\mathrm{SD}$ ), Switzerland (Sl, TT), Sweden (Sl) and the USA (Sl). By observing the cases of PRA in the pedigrees, the breeders have assumed ar inheritance in the following breeds (personal communications): Australian Cattle Dog, Collie, Dachshund, Engl. Cocker Spaniel, Entlebuch Cattledog, Irish Setter, Labrador Retriever, Miniature Poodle, Saarloos Wolfdog, Schapendoes, Sloughi and Tibetan Terrier. Experienced veterinarians confirmed the gPRA status of affected and unaffected dogs by ophthalmoscopy.

\subsection{Isolation of DNA and polymerase chain reaction (PCR)}

DNA was extracted from the peripheral blood according to standard protocols [23]. Genomic DNA from each affected dog as well as representative healthy dogs and obligatory carriers was screened for mutations. Parts of the PDE6D and PDE6G genes were amplified by PCR in a thermocycler (Biometra, Goettingen, Germany). PCR were performed in 96-well microtiter plates (Thermowell Costar Corning, NY). Each well contained 50 ng DNA in a $10 \mu \mathrm{L}$ reaction volume $100 \mathrm{mM}$ Tris $(\mathrm{pH} 8.3), 500 \mathrm{mM} \mathrm{KCl}, 1 \mathrm{U}$ Taq Polymerase (Genecraft, Münster, Germany), $0.2 \mathrm{mM}$ of each dNTP, $0.4 \mathrm{mM}$ of each primer and varying concentrations of $\mathrm{MgCl}_{2}$ (see Tab. II). For SSCP analysis, $0.06 \mu \mathrm{L}$ of $\left[\alpha^{32} \mathrm{P}\right] \mathrm{dCTP}\left(10 \mathrm{mCi} \cdot \mathrm{mL}^{-1}\right)$ was included in the PCR. 
Table I. Characteristics of dog breeds examined.

\begin{tabular}{|c|c|c|c|c|}
\hline Breed (abbreviation) & $\begin{array}{l}\text { Number } \\
\text { of dogs }\end{array}$ & Diagnosis & $\begin{array}{l}\text { Onset } \\
\text { forms } \\
\text { of } \\
\text { gPRA }\end{array}$ & $\begin{array}{l}\text { Age } \\
\text { distri- } \\
\text { bution } \\
\text { (year) }^{f}\end{array}$ \\
\hline Australian Cattle Dog (AC) & $\begin{array}{c}2 \\
19\end{array}$ & $\begin{array}{l}\text { gPRA-affected } \\
\text { normal }\end{array}$ & late $^{a}$ & $\begin{array}{c}10 \\
2-4\end{array}$ \\
\hline Pyrenean Sheepdog (BDP) & $\begin{array}{c}1 \\
42\end{array}$ & $\begin{array}{l}\text { gPRA-affected } \\
\text { normal }\end{array}$ & mid-onset $^{\mathrm{b}}$ & $\begin{array}{c}5 \\
1-10\end{array}$ \\
\hline Bernese Mountain Dog (BMD) & 1 & gPRA-affected & late ${ }^{b}$ & 10 \\
\hline Bolognese (Bo) & 1 & gPRA-affected & late $^{b}$ & 9 \\
\hline Collie (Co) & $\begin{array}{l}3 \\
1\end{array}$ & $\begin{array}{l}\text { gPRA-affected } \\
\text { normal }\end{array}$ & early ${ }^{\mathrm{cd}}$ & $\begin{array}{c}4-8 \\
8\end{array}$ \\
\hline Dachshund (wire; D) & $\begin{array}{l}20 \\
49\end{array}$ & $\begin{array}{l}\text { gPRA-affected } \\
\text { normal }\end{array}$ & variable $^{b}$ & $\begin{array}{l}1-13 \\
6-13\end{array}$ \\
\hline English Cocker Spaniel (ECS) & $\begin{array}{l}6 \\
6\end{array}$ & $\begin{array}{l}\text { gPRA-affected } \\
\text { normal }\end{array}$ & late ${ }^{\mathrm{cd}}$ & $\begin{array}{l}3-11 \\
6-14\end{array}$ \\
\hline Entlebuch Cattledog (EC) & $\begin{array}{l}17 \\
10\end{array}$ & $\begin{array}{l}\text { gPRA-affected } \\
\text { normal }\end{array}$ & late $e^{e}$ & $\begin{array}{c}5-13 \\
1-7\end{array}$ \\
\hline Golden Retriever (GR) & $\begin{array}{l}2 \\
8\end{array}$ & $\begin{array}{l}\text { gPRA-affected } \\
\text { normal }\end{array}$ & late $^{b}$ & $\begin{array}{c}5-10 \\
3-6\end{array}$ \\
\hline Irish Setter (IRS) & $\begin{array}{l}2 \\
1\end{array}$ & $\begin{array}{l}\text { gPRA-affected } \\
\text { normal }\end{array}$ & early ${ }^{c d} / l_{a t e}{ }^{b}$ & $\begin{array}{l}0.6-7 \\
3-13\end{array}$ \\
\hline Labrador Retriever (LR) & $\begin{array}{c}5 \\
139\end{array}$ & $\begin{array}{l}\text { gPRA-affected } \\
\text { normal }\end{array}$ & late $e^{\mathrm{cd}}$ & $\begin{array}{l}8-12 \\
3-13\end{array}$ \\
\hline Miniature Poodle (MP) & $\begin{array}{l}28 \\
15\end{array}$ & $\begin{array}{l}\text { gPRA-affected } \\
\text { normal }\end{array}$ & late ${ }^{\mathrm{cd}}$ & $\begin{array}{l}5-12 \\
1-12\end{array}$ \\
\hline Newfoundland (NF) & 1 & gPRA-affected & mid-onset $^{b}$ & 3 \\
\hline Polish Lowland Sheepdog & 1 & gPRA-affected & late ${ }^{b}$ & 9 \\
\hline Rottweiler (Ro) & 1 & gPRA-affected & late ${ }^{b}$ & 3 \\
\hline Saarloos Wolfdog (Sa) & $\begin{array}{c}7 \\
118\end{array}$ & $\begin{array}{l}\text { gPRA-affected } \\
\text { normal }\end{array}$ & late ${ }^{b}$ & $\begin{array}{c}7-9 \\
2-10\end{array}$ \\
\hline Scottish Terrier (ScT) & 1 & gPRA-affected & late $\mathrm{b}^{\mathrm{b}}$ & 6 \\
\hline Schapendoes (SD) & $\begin{array}{l}3 \\
7\end{array}$ & $\begin{array}{l}\text { gPRA-affected } \\
\text { normal }\end{array}$ & early ${ }^{\mathrm{d}}$ & $\begin{array}{l}2-6 \\
3-6\end{array}$ \\
\hline Sloughi (Sl) & $\begin{array}{c}5 \\
183\end{array}$ & $\begin{array}{l}\text { gPRA-affected } \\
\text { normal }\end{array}$ & mid-onset $^{\mathrm{b}}$ & $\begin{array}{c}2 \\
0.1-12\end{array}$ \\
\hline Tibetan Mastiff (TM) & $\begin{array}{l}2 \\
1\end{array}$ & $\begin{array}{l}\text { gPRA-affected } \\
\text { normal }\end{array}$ & & \\
\hline Tibetan Terrier (TT) & $\begin{array}{c}3 \\
93\end{array}$ & $\begin{array}{l}\text { gPRA-affected } \\
\text { normal }\end{array}$ & mid-onset ${ }^{c d}$ & $\begin{array}{c}7-8 \\
2-10\end{array}$ \\
\hline
\end{tabular}

${ }^{\mathrm{a}}$ [19]; ${ }^{\mathrm{b}}$ owners report/certificate of eye examination; ${ }^{\mathrm{c}}$ classifications of the different onset forms of gPRA in the reviews ([9] and [24]); ${ }^{\mathrm{d}}$ online information among PRA Today (http://www.sheepdog.com/diseases/pra/clinical); ${ }^{\mathrm{e}}[29] ;{ }^{\mathrm{f}}$ at the time when blood was taken for DNA analysis. 


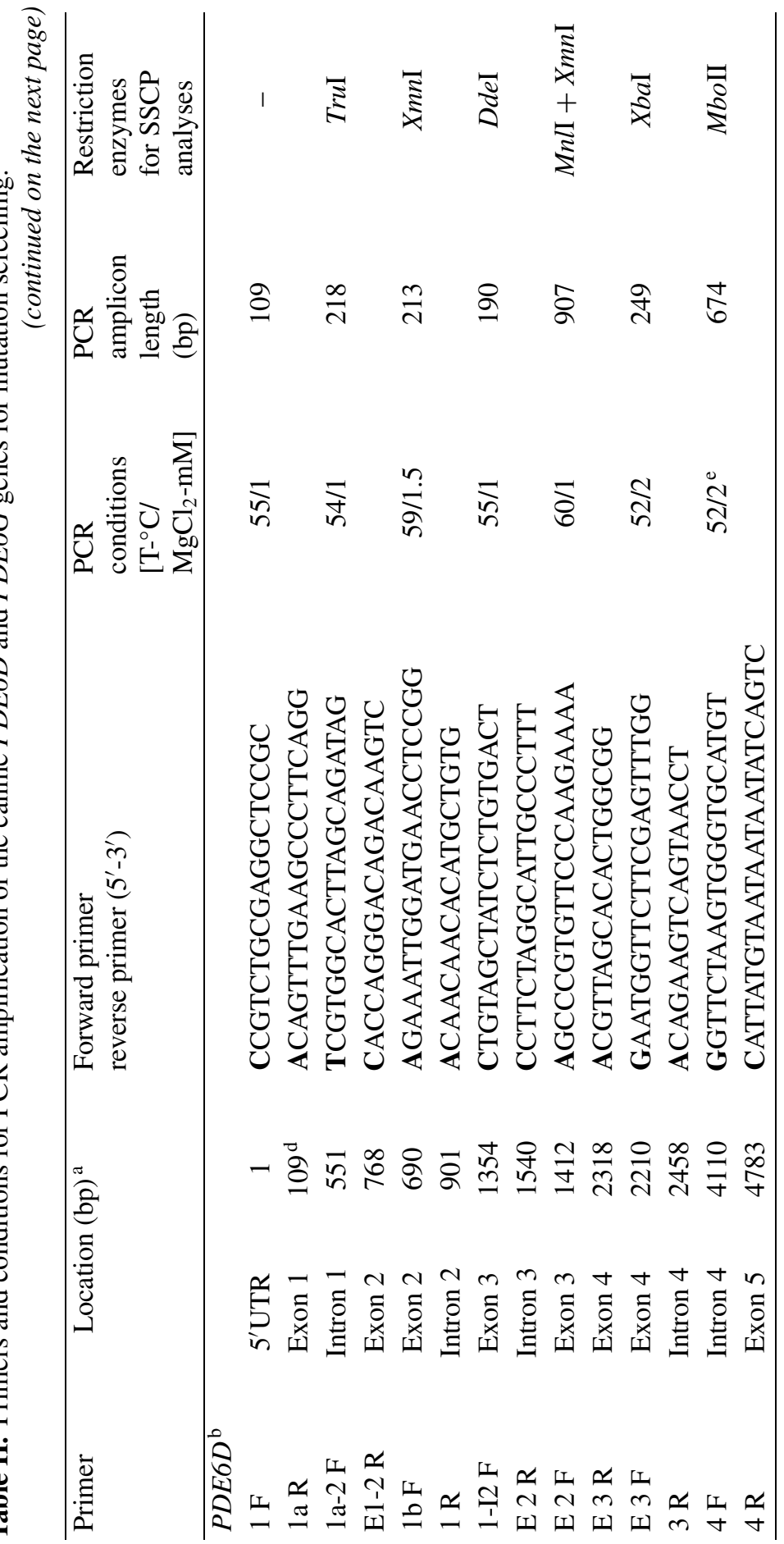


Canine $P D E 6 D$ and $P D E 6 G$ genes in gPRA

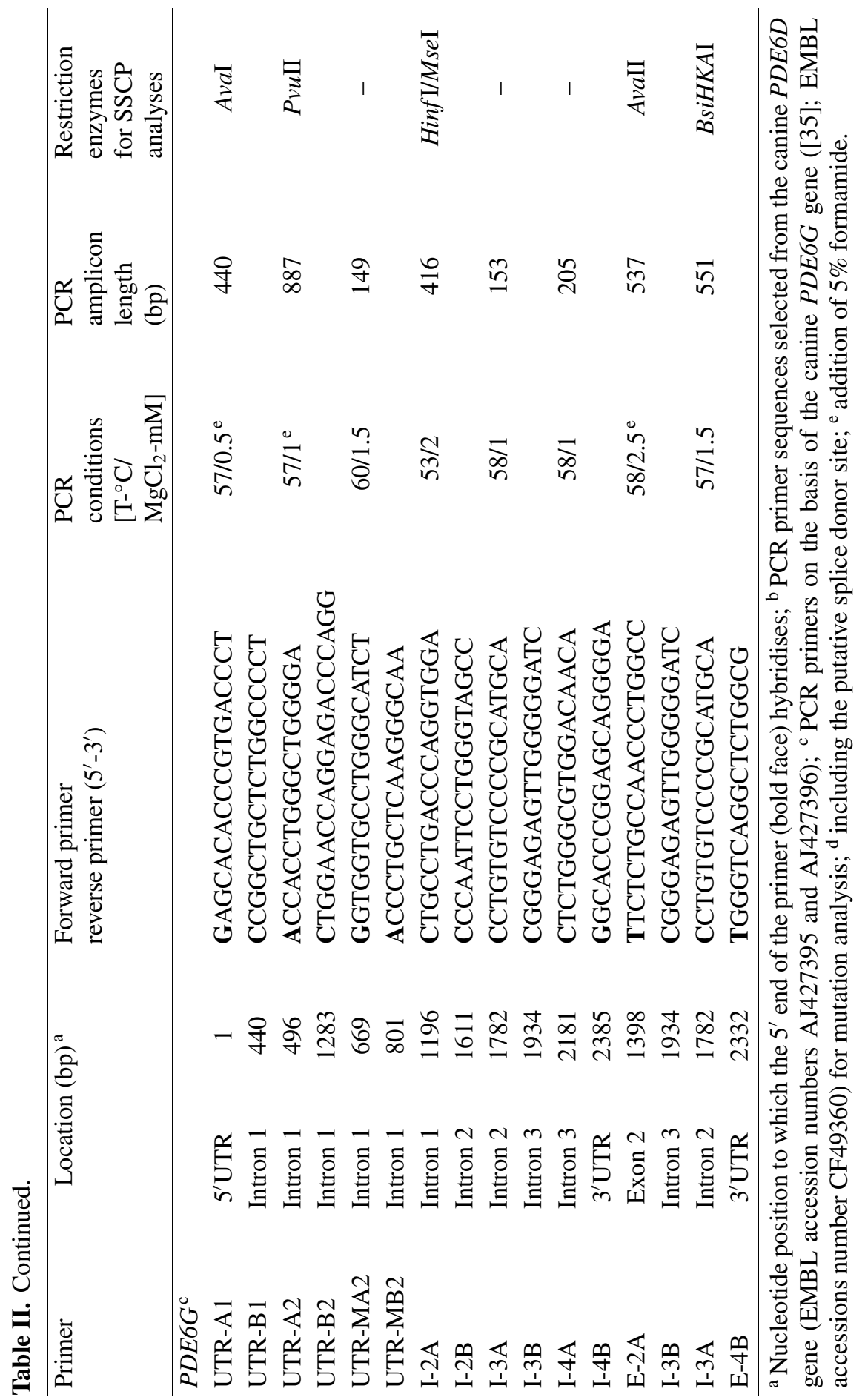


For genomic mutation analysis the following PCR procedure was applied: an initial denaturation step $\left(5 \min\right.$ at $\left.95^{\circ} \mathrm{C}\right), 10$ initial cycles $1{ }^{\circ} \mathrm{C}$ above the annealing temperature (see Tab. II), 22-25 cycles of $95^{\circ} \mathrm{C}$ (30 s), annealing temperature $(30 \mathrm{~s})$, elongation at $72{ }^{\circ} \mathrm{C}(30 \mathrm{~s})$ and a final elongation step at $72{ }^{\circ} \mathrm{C}(3 \mathrm{~min})$.

\subsection{Cloning and identification of exon/intron junctions of intron 1 of the PDE6D gene}

Parts of the PDE6D gene were cloned from a genomic canine $\lambda$-DNA library $\left(\lambda\right.$ FIX ${ }^{\circledR}$ II Library; host: $E$. coli XL1-Blu MRA (P2) Stratagene, La Jolla, CA, USA) according to the Stratagene standard protocol. Recombinant $\lambda$ DNA was fixed to Hybond ${ }^{\mathrm{TM}}-\mathrm{N}$ Nylon membranes (Amersham, Buckinghamshire, UK) and UV-crosslinked $\left(1^{\prime} 70 \mathrm{~mJ} \cdot \mathrm{cm}^{-2}\right)$. The library was screened using PCR amplificates from exon 2 corresponding to nucleotide positions 109-321 of the canine PDE6D gene (EMBL accession number AF113996). These probes were labelled using $\left[\alpha^{32} \mathrm{P}\right]$ dATP and the Megaprime Labelling System (Amersham, Buckinghamshire, UK). Hybridisations were performed as described [8] and hybridising clones were isolated and plaque purified [28]. Exon 1 of the PDE6D gene was not identified in the clones. To search for sequences of intron 1 of the PDE6D gene, the isolated $\lambda$ clones were digested with HindIII and subcloned in pBluescript ${ }^{\circledR} \mathrm{II}+$ phagemid (Stratagene, La Jolla; [27]). Parts of the cloned intron 1 were amplified by PCR using the T7 primer (for the $\lambda$ phage) and an exonic primer specific for exon 2 in order to characterize the intron-exon boundary of the PDE6D gene (EMBL accession number AJ427396). For annealing temperatures see Table II. Long-range PCR using the Elongase enzyme mix (GIBCO BRL, Karlsruhe, Germany) was performed from genomic DNA in order to identify the splice donor site of intron 1 according to the recommendations of the manufacturer. Sequencing reactions of 2-3 clones including exon 2, introns 1 and 2 were carried out by the dideoxy-chain termination method using the Big Dye Terminator (Perkin-Elmer, Norwalk, CT, USA) according to the manufacturer's instructions. All sequencing reactions were run on an automated DNA sequencer (Applied Biosystems 373 XL, Foster City, USA) and analysed using the corresponding software.

\subsection{PCR-SSCP and DNA sequence analyses of the PDE6D and PDE6G genes}

Primers were created for mutation screening of intron 1 after DNA sequence analysis of the genomic PDE6D clones and genomic sequences of the PDE6D and PDE6G genes (CF49360; see Tab. II). SSCP samples were treated as described $[10,11]$. PCR products were digested dependent on the lengths of the fragments [17] with different restriction enzymes (see Tab. II). The sequence 
variations in the PDE6D gene were investigated in intron 3 (with $M n l \mathrm{I} ; \mathrm{XmaI}$ ) and exon 5 (with $\mathrm{Hae}$ III) using restriction fragment length polymorphism (RFLP) analysis. Three $\mu \mathrm{L}$ of the PCR were denatured with $7 \mu \mathrm{L}$ of loading buffer (95\% deionised formamide $10 \mathrm{mM} \mathrm{NaOH}, 20 \mathrm{mM}$ EDTA, $0.06 \%$ (w/v) xylene cyanol, and $0.06 \%$ (w/v) bromophenol blue). The samples were heated to $95^{\circ} \mathrm{C}$ for $5 \mathrm{~min}$ and snap cooled on ice. Three $\mu \mathrm{L}$ aliquots of the singlestranded fragments were separated through two sets of $6 \%$ polyacrylamide (acrylamide/bisacrylamide: 19/1) gels, one set containing 10\% glycerol, and the other containing 5\% glycerol and $1 \mathrm{M}$ urea. The gels were run with $1 \mathrm{X}$ TBE buffer at 50-55 W for 4-6 h at $4{ }^{\circ} \mathrm{C}$. All gels were dried and subjected to autoradiography over night. All DNA samples with band shifts evidenced by SSCP electrophoresis were purified and cycle sequenced as described above.

\section{RESULTS AND DISCUSSION}

\subsection{Identification of intron 1 in the canine PDE6D gene}

It was demonstrated that the human $P D E 6 D$ gene comprises five exons [21] vs. four exons in dogs [35]. Since the described "exon 1" of the PDE6D gene of dogs could not be amplified from genomic DNA, an additional intron was also assumed in dogs. Therefore, three genomic DNA clones with parts of the PDE6D gene were isolated from a $\lambda$-DNA library. Yet the $5^{\prime}$ part of "exon 1" was always lacking in these clones. Comparisons with the recently published human genomic DNA (EMBL accession number AC073476) showed an intron 1 size of 41877 base pairs (bp). Therefore, the canine intron 1 may well exceed clonable sizes in $\lambda$-phages. Also, the exact size of intron 1 could not be determined via long range PCR of genomic DNA. Parts of intron 1 were sequenced after subcloning of the inserts of the $\lambda$-phages and PCR (splice acceptor site intron1/exon2: atattgatcagAAATTGGATGAA).

\subsection{Mutation analysis}

All coding exons of the PDE6D and PDE6G genes were investigated by PCR-SSCP analysis including splice donor and acceptor sites as well as adjacent intronic sequences except for $20 \mathrm{bp}$ (primer sequence) of exon 1 and the splice donor site of intron 1 in the PDE6D gene. The DNA of 22 dog breeds including 114 gPRA-affected animals are covered in this study. For six of these breeds either the causative gPRA mutations (Irish Setter [31], and Sloughi [12]) or linked markers for the progressive rod cone degeneration ( $p r c d$ ) form of gPRA are already known (Australian Cattle Dog, English Cocker Spaniel, Labrador Retriever, Miniature Poodle; patented by OptiGen, USA). The PDE6G gene is located near the prcd region, but is excluded as a cause for RP 17 in man [4], the homologous gPRA form in these 
breeds [1]. The other 16 dog breeds were included in the analysis, because all polymorphisms identified in these six breeds could then be excluded as a causative mutation for gPRA in the remaining breeds. A second gPRA form may exist in Irish Setters since one affected Setter showed late manifestation of gPRA symptoms without the typical PDE6B mutation. Because of similar phenotypic heterogeneity also in Miniature poodles, two forms of gPRA are possible (see http://www.optigen.com).

\subsubsection{PDE6D gene}

In the coding region of the $P D E 6 D$ gene, no polymorphisms were identified. To identify intragenic SNP markers for the exclusion of the PDE6D gene as a cause for gPRA, the $3^{\prime}$ UTR and intron 3 were screened completely. Sequencing of the canine PDE6D gene revealed several differences to the published data [35]: in intron 3 five exchanges and in the $3^{\prime}$ UTR a single sequence variation were identified in all genomic DNA. Furthermore SNP were observed in intron $2(874 \mathrm{~A} \rightarrow \mathrm{T}), 3(1808 \mathrm{~A} \rightarrow \mathrm{G} ; 2166 \mathrm{~T} \rightarrow \mathrm{A})$ and the untranslated exon $5(4439 \mathrm{C} \rightarrow \mathrm{T}$; 4483T $\rightarrow \mathrm{C} ; 4664 \mathrm{C} \rightarrow \mathrm{T})$ of different dog breeds in the PDE6D gene (Tab. III).

Table III. PDE6D and PDE6G sequence variations and heterozygous patterns in gPRA-affected dogs.

\begin{tabular}{|c|c|c|c|c|}
\hline Gene & Location & $\begin{array}{l}\text { Sequence } \\
\text { variation }\end{array}$ & $\begin{array}{l}\text { Amino } \\
\text { acid } \\
\text { exchange }\end{array}$ & $\operatorname{Breed}(\mathrm{s})^{\mathrm{a}}$ \\
\hline$P D E 6 D^{\mathrm{b}}$ & Intron 2 & $847 \mathrm{~A} \rightarrow \mathrm{T}$ & - & LR, NF \\
\hline \multirow[t]{2}{*}{ PDE6D } & Intron 3 & $1808 \mathrm{~A} \rightarrow \mathrm{G}$ & - & $\begin{array}{l}\text { Bo, BMD, Co, EC, LR, } \\
\text { MP, NF, Ro, Sa, SD }\end{array}$ \\
\hline & & $2166 \mathrm{~T} \rightarrow \mathrm{A}$ & - & BMD, EC, LR, Ro \\
\hline \multirow[t]{3}{*}{ PDE6D } & 3'UTR Exon 5 & $4439 \mathrm{C} \rightarrow \mathrm{T}$ & - & SD \\
\hline & & $4483 \mathrm{~T} \rightarrow \mathrm{C}$ & - & $\begin{array}{l}\text { AC, BMD, Co, ECS, } \\
\text { EC, LR, MP, Ro, Sl }\end{array}$ \\
\hline & & $4664 \mathrm{C} \rightarrow \mathrm{T}$ & - & $\begin{array}{l}\text { AC, D, Co, ECS, EC, } \\
\text { IRS, LR, MP, Ro, SD, Sl }\end{array}$ \\
\hline$P D E 6 G^{\mathrm{c}}$ & Intron 1 & $744 \mathrm{G} \rightarrow \mathrm{A}$ & - & $\begin{array}{l}\text { AC, BMD, Co, D, ECS, } \\
\text { EC, GR, IRS, LR, MP, } \\
\text { Ro, Sa, ScT, SD, TT }\end{array}$ \\
\hline \multirow[t]{2}{*}{ PDE6G } & Intron 2 & $1662 \mathrm{C} \rightarrow \mathrm{T}$ & - & ECS, EC, LR, Sa, SD \\
\hline & & $1694 \mathrm{G} \rightarrow \mathrm{A}$ & - & ECS, EC, LR, Sa, SD \\
\hline PDE6G & Exon 4 & $2285 \mathrm{G} \rightarrow \mathrm{A}$ & (L78L) & $(\mathrm{LR})^{*}$ \\
\hline
\end{tabular}

${ }^{\mathrm{a}}$ For abbreviations see Table I; ${ }^{\mathrm{b}}$ position of SNP of the PDE6D gene refer to EMBL accession number AJ427396; ' $\mathrm{SNP}$ of the PDE6G gene refer to EMBL accession number CF49360; * heterozygous sequence variation in healthy Labrador Retrievers. 


\subsubsection{PDE6G gene}

In the coding region of the $P D E 6 G$ gene (exon 4) a "silent" sequence variation was identified at position $2285(\mathrm{G} \rightarrow \mathrm{A})$ in healthy Labrador retrievers. The additional PCR-SSCP analysis of the complete $5^{\prime} \mathrm{UTR}$, parts of the $3^{\prime} \mathrm{UTR}$ and the two introns revealed informative SNP in intron 1, (position 744, $\mathrm{G} \rightarrow \mathrm{A}$ ) and in intron 2 (position 1662; $\mathrm{C} \rightarrow \mathrm{T}$; position 1694, G $\rightarrow$ A; see Tab. III).

\subsection{Exclusion of PDE6D and PDE6G genes for ar transmitted gPRA}

The identified intronic SNP were found in the heterozygous and homozygous states in gPRA affected and unaffected dogs of different breeds (see Tab. III). The breeding history, small population sizes and gPRA abundance in the investigated breeds point together to a few meiotic events in which intragenic recombinations could have occurred between any unidentified mutation in the PDE6 loci and the SNP investigated here. Although the complete promoters and all introns of the PDE6D and PDE6G genes could not be included in the SSCP analyses, the observed sequence variations can be used as intragenic markers for excluding the PDE6D and PDE6G genes as causing the ar transmitted eye disease. gPRA is most commonly inherited as an ar transmitted trait although in two dog breeds it is sex linked (Samojed and Siberian Husky [2]) and in one there is autosomal dominant (Mastiff) inheritance [18]. By assuming ar inheritance, we excluded PDE6D as a candidate gene for gPRA via intragenic SNP in 15 breeds: Australian Cattle Dog, Bernese Mountain Dog, Bolognese, Collie, Entlebuch Cattledog, Dachshund, English Cocker Spaniel, Irish Setter, Labrador Retriever, Miniature Poodle, Newfoundland, Rottweiler, Saarloos Wolfdog, Schapendoes and Sloughi. Similarly, in 15 breeds the PDE6G gene was excluded for the assumed ar gPRA in the Australian Cattle Dog, Bernese Mountain Dog, Collie, Dachshund, English Cocker Spaniel, Entlebuch Cattledog, Golden Retriever, Irish Setter, Labrador Retriever, Miniature Poodle, Rottweiler, Saarloos Wolfdog, Scottish Terrier, Schapendoes and Tibetan Terrier. Some dog breeds are only represented by one gPRA affected individual (Tab. I). For these breeds the exclusion of the PDE6D and PDE6G genes is not definitive, since the possibility of false clinical diagnosis is not ruled out completely. Fortunately, the identified SNP in the PDE6D and PDE6G genes occurred in several breeds. Therefore, it is possible to use these markers in further studies [33].

\section{ACKNOWLEDGEMENTS}

We thank Bodo Janke for the laboratory work, the dog owners for blood samples, the veterinarians of the Dortmunder Ophthalmologenkreis (DOK) for the ophthalmologic investigations of the dogs and for the support of different breed clubs. These studies were supported by the Gesellschaft für kynologische Forschung (GKF; Bonn, Germany). 


\section{REFERENCES}

[1] Acland G.M., Ray K., Mellersh C.S., Gu W., Langston A.A., Rine J., Ostrander E.A., Aguirre G.D., Linkage analysis and comparative mapping of canine progressive rod-cone degeneration (prcd) establishes potential locus homology with retinitis pigmentosa (RP17) in humans, Proc. Natl. Acad. Sci. USA 95 (1998) 3048-3053.

[2] Aguirre G., Genes and diseases in man and models, Prog. Brain Res. 131 (2001) 663-678.

[3] Baehr W., Devlin M.J., Applebury M.L., Isolation and characterization of bovine photoreceptor cGMP phosphodiesterase, J. Biol. Chem. 254 (1979) 1166911677.

[4] Bardien-Kruger S., Greenberg J., Tubb B., Bryan J., Queimado L., Lovett M., Ramesar RS., Refinement of the RP17 locus for autosomal dominant retinitis pigmentosa, construction of a YAC contig and investigation of the candidate gene retinal fascin, Eur. J. Hum. Gene. 7 (1999) 332-338.

[5] Bowes C., Li T., Danciger M., Retinal degeneration in the rd mouse is caused by a defect in the $\beta$ subunit of rod cGMP-phosphodiesterase, Nature 347 (1990) 677-680.

[6] Bowes C., Li T., Frankel W.N., Danciger M., Coffin J.M., Applebury M.L., Farber D.B., Localization of a retroviral element within the $r d$ gene coding for the $\beta$ subunit of cGMP-phosphodiesterase, Proc. Natl. Acad. Sci. USA 90 (1993) 2955-2959.

[7] Breen M., Jouquand S., Renier C., Mellersh C.S., Hitte C., Holmes N.G., Cheron A., Suter N., Vignaux F., Bristow A.E., Priat C., McCann E., André C., Boundy S., Gitsham P., Thomas R., Bridge W., Spriggs H.F., Ryder E.J., Curson A., Sampson J., Ostrander E.A., Binns M., Galibert F., Chromosome-specific single locus FISH probes allow anchorage of a 1,800 marker integrated radiationhybrid/linkage map of the domestic dog genome to all chromosomes, Genome Res. 11 (2001) 1784-1795.

[8] Church G.M., Gilbert W., Genomic sequencing, Proc. Natl. Acad. Sci. USA 81 (1984) 1991-1995.

[9] Clements P.J.M., Sargan D.R., Gould S.M., Petersen-Jones S.M., Recent advances in understanding the spectrum of canine generalised progressive retinal atrophy, J. Small Anim. Pract. 37 (1996) 155-162.

[10] Dekomien G., Klein W., Epplen J.T., Polymorphisms in the canine rod transducin gene and exclusion as cause for generalised progressive retinal atrophy (gPRA), J. Exp. Anim. Sci. 39 (1998) 86-90.

[11] Dekomien G., Epplen J.T., Exclusion of the PDE6A gene for generalised progressive retinal atrophy in 11 breeds of dogs, Anim. Genet. 31 (2000) 135-139.

[12] Dekomien G., Runte M., Gödde R., Epplen J.T., Generalised progressive retinal atrophy of Sloughi dogs is due to an 8-bp insertion in exon 21 of the PDE6B gene, Cytogenet. Cell Genet. 90 (2000) 261-267.

[13] Deterre P., Bigay J., Forquet F., Robert M., Chabre M., cGMP phosphodiesterase of retinal rods is regulated by two inhibitory subunits, Proc. Natl. Acad. Sci. USA 85 (1988) 2424-2428. 
[14] Ershova G., Derre J., Chetelin S., Nancy V., Berger R., Kaplan J., Munnich A., de Gunzburg J., cDNA sequence, genomic organization and mapping of PDE6D, the human gene encoding the delta subunit of the cGMP phosphodiesterase of retinal rod cells to chromosome 2q36, Cytogenet. Cell Genet. 79 (1997) 139-141.

[15] Florio S.K., Prusti R.K., Beavo J.A., Solubilization of membran-bound rod phosphodiesterase by the rod phosphodiesterase recombinant delta subunit, J. Biol. Chem. 271 (1996) 24036-24047.

[16] Huang S.H., Pittler S.J., Huang X., Oliveira L., Berson E.L., Dryja T.P., Autosomal recessive retinitis pigmentosa caused by mutations in the alpha subunit of rod cGMP phosphodiesterase, Nat. Genet. 11 (1995) 468-471.

[17] Jäckel S., Epplen J.T., Kauth M., Miterski B., Tschentscher F., Epplen C., PCRSSCP or how to detect reliably and efficiently each sequence variation in many samples and many genes, Electrophoresis 19 (1998) 3055-3061.

[18] Kijas J.W., Cideciyan A.V., Aleman T.S., Pianta M.J., Pearce-Kelling S.E., Miller B.J., Jacobson S.G., Aguirre G.D., Acland G.M., Naturally occurring rhodopsin mutation in the dog causes retinal dysfunction and degeneration mimicking human dominant retinitis pigmentosa, Proc. Natl. Acad. Sci. USA 99 (2002) 6328-6333.

[19] Laratta L.J., Sims M.H., Brooks D.E., Progressive retinal degeneration in the Australian cattle dog, Proc. Am. Coll. Vet. Ophthal. 19 (1988) 9.

[20] Li N., Florio S.K., Pettenati M.J., Characterization of human and mouse rod cGMP-phosphodiesterase delta subunit $(P D E 6 D)$ and chromosomal localization of the human gene, Genomics 49 (1998) 76-82.

[21] Lorenz B., Migliaccio C., Lichtner P., Meyer C., Strom T.M., D’Urso M., Becker J., Ciccodicola A., Meitinger T., Cloning and gene structure of the rod cGMP phosphodiesterase delta subunit gene (PDED) in man and mouse, Europ. J. Hum. Genet. 6 (1998) 283-290.

[22] McLaughlin M.E., Ehrhard T.L., Berson E.L., Dryja T.P., Recessive mutations in the gene encoding the beta-subunit of rod phosphodiesterase in patients with retinitis pigmentosa, Nature Genet. 4 (1993) 130-134.

[23] Miller S.A., Dykes D.D., Polesky H.F., A simple salting out procedure for extracting DNA from human nucleated cells, Nucleic Acids. Res. 16 (1988) 1215.

[24] Petersen-Jones S.M., A Review of research to elucidate the cause of the generalized progressive retinal atrophies, Vet. J. 155 (1998) 5-18.

[25] Petersen-Jones S.M., Entz D.D., Sargan D.R., cGMP phosphodiesterase- $\alpha$ mutation causes progressive retinal atrophy in the cardigan welsh corgi dog, Invest. Ophthalmol. Vis. Sci. 40 (1999) 1637-1644.

[26] Pittler S.J., Baehr W., Identification of a nonsense mutation in the rod photoreceptor cGMP phosphodiesterase $\beta$ subunit gene of the rd mouse, Proc. Natl. Acad. Sci. USA 90 (1991) 8322-8326.

[27] Runte M., Dekomien G., Epplen J.T., Evaluation of RDS/Peripherin and ROM1 as candidate genes in generalised progressive retinal atrophy and exclusion of digenic inheritance, Anim. Genet. 31 (2000) 223-227.

[28] Sambrook J., Fritsch E.F., Maniatis T., Molecular cloning: A laboratory Manual, 2nd edn., Cold Spring Harbor, NY: Cold Spring Harbor Laboratory Press, 1989. 
[29] Spiess B.M., Inherited ocular diseases in the Entlebucher Mountain Dog, Schweiz Arch. Tierheilk. 136 (1994) 105-110.

[30] Stryer L., Vision: From photon to perception, Proc. Natl. Acad. Sci. USA 93 (1996) 557-559.

[31] Suber M.L., Pittler S.J., Qin N., Wright G.C., Holcombe V., Lee R.H., Craft C.M., Lolley R.N., Baehr W., Irish setter dogs affected with rod/cone dysplasia contain a nonsense mutation in the rod cGMP Phosphodiesterase beta-subunit gene, Proc. Natl. Acad. Sci. USA 90 (1993) 3968-3972.

[32] Tsang S.H., Yamashita C., Tanabe T., Retinal degeneration in mice lacking the gamma subunit of the rod cGMP phosphodiesterase, Science 272 (1996) 1026-1029.

[33] Vignal A., Milan D., SanCristobal M., Eggen A., A review on SNP and other types of molecular markers and their use in animal genetics, Genet. Sel. Evol. 34 (2002) 275-305.

[34] Wang W., Acland M.G., Ray K., Aguirre G.D., Evaluation of cGMPPhosphodiesterase (PDE) subunits for causal association with rod-cone Dysplasia 2 (rcd2), a canine model of abnormal retinal cGMP metabolism, Exp. Eye Res. 69 (1999) 445-453.

[35] Wang W., Zhang Q., Acland M.G., Mellersh C., Ostrander E.A., Ray K., Aguirre G.D., Molecular characterization and mapping of canine $c G M P$ phosphodiesterase delta subunit (PDE6D), Gene 236 (1999) 325-332.

[36] Yang F., O’Brien P.C., Milne B.S., Graphodatsky A.S., Solanky N., Trifonov V., Rens W., Sargan D., Ferguson-Smith M.A., A complete comparative chromosome map for the dog, red fox, and human and its integration with canine genetic maps, Genomics 62 (1999) 189-202.

To access this journal online: www.edpsciences.org 